\title{
Review
}

\section{Host microenvironment in breast cancer development Inflammatory and immune cells in tumour angiogenesis and arteriogenesis}

\author{
Joanne L Yu and Janusz W Rak \\ Henderson Research Centre, McMaster University, Hamilton, Ontario, Canada \\ Corresponding author: Janusz W Rak (e-mail jrak@thrombosis.hhscr.org)
}

Received: 5 December 2002 Accepted: 8 January Published: 3 February 2003

Breast Cancer Res 2003, 5:83-88 (DOI 10.1186/bcr573)

(C) 2003 BioMed Central Ltd (Print ISSN 1465-5411; Online ISSN 1465-542X)

\begin{abstract}
Breast cancer progression is associated with and dependent upon robust neovascularization. It is becoming clear that tumour-associated 'normal' cells, such as immune/inflammatory cells, endothelial cells and stromal cells, conspire with cancer cells in promoting this process. In particular, infiltrating immune/inflammatory cells secrete a diverse repertoire of growth factors and proteases that enable them to enhance tumour growth by stimulating angiogenesis and, as we suggest here, by promoting 'tumour arteriogenesis' - enlargement of feeding vessels supplying the expanding tumour capillary bed. Macrophages and their chemoattractants (e.g. macrophage chemoattractant protein-1) are critical for the arteriogenic process in ischaemia, and probably also in breast neoplasia. A better understanding of these various cellular and molecular constituents of breast cancer neovascularization may be useful in designing more effective therapies.
\end{abstract}

Keywords: angiogenesis, arteriogenesis, cancer, immunity, inflammation

\section{Introduction}

Infiltration of lymphocytes, macrophages, mast cells and neutrophils is a hallmark of inflammatory, defense and tissue repair reactions, which are often present in tumours $[1,2]$. Various types of tumour-infiltrating lymphocytes, including cytotoxic T cells, natural killer cells and lymphokine activated killer cells, are viewed as potential effectors of antitumour immunity and may oppose tumour expansion [3]. Tumour-associated macrophages (TAMs) constitute a major component of the leucocytic infiltrate [4], and activated macrophages have been shown to possess both direct and indirect tumouricidal activity $[5,6]$. However, evidence increasingly suggests that these cells may in fact symbiotically promote rather than inhibit tumour growth and development.

Macrophages, lymphocytes and mast cells have all been implicated in another host-dependent process, namely that of angiogenesis [7-9]. Clinical studies have linked the extent of immune/inflammatory cell infiltration with increased blood vessel density and poor prognosis in various types of cancer, suggesting that these cells may contribute to tumour progression in large part by stimulating tumour neovascularization $[10,11]$. Several studies in mice support these observations, and demonstrate a critical role for macrophage and mast cell infiltration in promoting angiogenesis during the earliest stages of neoplastic progression $[9,12,13]$.

\section{Molecular regulators of inflammatory cell infiltration into tumours}

The infiltration of host immune cells into tumours is regulated by cues from the tumour microenvironment, in combination with tumour-derived chemokines, which together influence the adhesion, extravasation and migration of leucocytes. Breast carcinomas are known to contain a high proportion of infiltrating leucocytes, particularly TAMs. Macrophages are a heterogeneous population of cells that 
belong to the mononuclear phagocyte system and are derived from blood-borne monocytes that migrate into tissues, where they undergo final differentiation. Tumour hypoxia is an important stimulus for extravasation of monocytes [14], which migrate into the tumour tissue along gradients of chemoattractants, and these TAMs become immobilized in ischaemic, necrotic areas of tumours, where they can remain for an extended time [15-18].

Many studies have linked increased TAM density to poor prognosis in breast cancer [15,19-21], and in fact certain genetic alterations that increase the malignancy of the tumour may concomitantly increase the degree of macrophage infiltration. A strong association has been reported between HER-2, c-myc and int-2 oncogene amplification in breast tumour samples and the density of lymphocyte infiltration of the tumour [22]. In inflammatory breast cancer, expression of constitutively activated RhoC oncoprotein is associated with concomitant upregulation of both angiogenic (vascular endothelial growth factor [VEGF]) and inflammatory (IL-6) cytokines, leading to the formation of a specific type of inflammatory/angiogenic stroma in this particularly aggressive form of disease [23].

Some of the tumour molecular alterations that increase macrophage infiltration and macrophage-mediated angiogenesis include increased expression of monocyte chemoattractant protein (MCP)-1 and VEGF, both of which are highly expressed in breast tumour cells. MCP-1, a member of the $\mathrm{C}-\mathrm{C}$ chemokine family, is involved in monocyte and T-lymphocyte migration, and is secreted by many human and murine tumour cells in addition to activated stromal cells $[24,25]$. MCP-1 expression in tumour cells is significantly correlated with the extent of TAM infiltration $[26,27]$, and in particular both MCP-1 and VEGF expression have been positively correlated with TAM infiltration, angiogenesis and poor survival in breast cancer [28-30].

VEGF is a potent angiogenic growth factor that is overexpressed in the majority of human cancers [31]. VEGF produced by tumours promotes the proliferation, survival and migration of endothelial cells by binding to its receptors, namely VEGF receptor (VEGFR)-1 and VEGFR-2, which are expressed on the endothelial cell surface. However, in addition to these direct effects on endothelial cells, VEGF also stimulates monocyte migration through VEGFR-1 [32], which is expressed on monocytes and macrophages, as well as on endothelial cells [33,34]. A positive correlation between VEGF expression and degree of macrophage infiltration has been observed in invasive breast carcinoma $[28,35]$ and other malignancies $[36,37]$. Placental growth factor and VEGF-C - two VEGF-related tumour-derived growth factors - can also stimulate monocyte chemotaxis $[38,39]$. Placental growth factor may also act as a survival factor for both endothelial cells and macrophages [40].
The other important factor responsible for increased macrophage infiltration in breast cancer is the macrophage colony-stimulating factor (CSF)-1; this is a haematopoietic growth factor that regulates the proliferation, survival and differentiation of monocytes and macrophages, which express the CSF-1 receptor [41]. Although it is secreted by many types of cells, increased expression of CSF-1 occurs in breast tumours, where it has been associated with high TAM infiltration and poor prognosis [42-44]. The critical importance of CSF-1 production, not only for macrophage recruitment but also for tumour vascularization and progression, has also been demonstrated in transgenic mouse models of breast cancer $[45,46]$.

\section{Contribution of inflammatory cells to tumour angiogenesis and lymphangiogenesis}

Although tumour cells themselves promote the recruitment and expansion of their own blood supply, tumour-associated immune/inflammatory cells can modify and contribute to this process by supplying a repertoire of growth factors, cytokines and proteases comparable to that secreted by tumour cells themselves (summarized in Table 1). Inflammatory cells can produce a myriad of cytokines and growth factors, many of which are proangiogenic, and directly stimulate the migration and proliferation of endothelial cells. For example, macrophages, mast cells and neutrophils all secrete VEGF, IL-8 and transforming growth factor- $\alpha$. Some of these molecules, for example VEGF, act not only on endothelial cells but also stimulate migration of further inflammatory cells into the tumour, potentially forming self-perpetuating positive feedback loops. Factors that increase vascular permeability are also proangiogenic because they promote deposition of fibrin, providing a matrix favourable for endothelial cell and leucocyte migration. For example, macrophage-derived VEGF, substance $P$, platelet-activating factor and prostaglandins induce vessel hyperpermeability [47]. Histamine, which is stored and released by mast cells, has wide-ranging biological effects that include proangiogenic activity [48].

Inflammatory cells also secrete a variety of proteases that degrade and remodel the extracellular matrix [47]. For example, macrophages, mast cells, neutrophils and lymphocytes all secrete matrix metalloprotease (MMP)- 9 - a MMP that has emerged as an important modulator of angiogenesis and tumour development [49]. Some of these proteases (e.g. urokinase-type plasminogen activator and heparanase) release proangiogenic growth factors (e.g. basic fibroblast growth factor) that are sequestered by heparan sulphate proteoglycans in the extracellular matrix. However, it should be kept in mind that MMPs, including MMP-9, may also have an antiangiogenic effect (at later stages) by processing the $\alpha 3$ chain of type IV collagen to the angiogenesis inhibitor tumstatin [50]. Furthermore, at least one macrophage-derived protease, namely 
MMP-12 (metalloelastase), has been shown to generate angiostatin, an endogenous angiogenesis inhibitor, from its precursor - plasminogen [51]. MMP-7 and MMP-9 have also been shown to have angiostatin-converting activity [52].

It should be noted that not all of the growth factors and cytokines released by inflammatory cells are proangiogenic. For example, macrophages secrete thrombospondin-1, interferon- $\alpha$ and interferon- $\gamma$, which are antiangiogenic. Many cytokines (e.g. transforming growth factor- $\beta$, IL-1 $\beta$, IL-6, tumour necrosis factor- $\alpha$ ) are known to have pleiotropic effects, stimulating angiogenesis under certain conditions and inhibiting it under others [47]. It is not known how the net proportion of the various proangiogenic or antiangiogenic activities of macrophages and other inflammatory cells is regulated. However, this balance between angiogenesis promoting, inhibiting and modulating influences at given times and locations in the tumour microenvironment clearly has a potential to determine the overall course and dynamics of blood vessel formation.

Finally, immune/inflammatory cells may also promote tumour lymphangiogenesis by secreting the lymphangiogenic growth factors VEGF-C and VEGF-D $[53,54]$. The formation of peritumoural lymphatic vessels, which in one study correlated with the extent of TAM recruitment, represents an important conduit for the metastasis of tumours to regional lymph nodes, with major implications for patient prognosis $[54,55]$.

\section{'Tumour arteriogenesis': the possible role of inflammatory cells}

Although various processes that affect tumour microcirculation (both blood and lymphatic) have attracted considerable attention and are being extensively characterized at the molecular level, there has been essentially no emphasis on the events that must implicitly occur in the vascular tree upstream of the site of active angiogenesis. The recruitment of large numbers of capillary microvessels during tumour growth (as a result of angiogenesis) considerably increases the intratumoural capillary volume - a circumstance that would be expected to require the concurrent expansion of upstream arterioles and downstream venules (i.e. tumour 'feeding vessels'). Indeed, such dilatations of feeding vessels have been observed using angiography in cancer patients [56]. This peritumoural remodelling and expansion of pre-existing arteries and arterioles probably involves processes similar to collateral vessel formation or 'arteriogenesis', which occurs during ischaemic limb or heart disease. We postulate that an analogous process of 'tumour arteriogenesis' must accompany angiogenic expansion of the microvasculature, and hence such a process could similarly be viewed as a rate-limiting and targetable event during tumour expansion.
Table 1

Angiogenesis modulators produced by inflammatory/immune cells

\begin{tabular}{|c|c|c|c|}
\hline Cell type & Activity & Molecule & Reference \\
\hline \multirow[t]{14}{*}{ Macrophages } & Proangiogenic & VEGF & [62] \\
\hline & & TGF- $\alpha$ & {$[63,64]$} \\
\hline & & IL-8 & {$[65]$} \\
\hline & & bFGF & {$[66]$} \\
\hline & & TP & {$[30,67]$} \\
\hline & & PDGF & {$[68]$} \\
\hline & & Substance P & [69] \\
\hline & & Prostaglandins & [70] \\
\hline & Antiangiogenic & TSP-1 & [71] \\
\hline & & IFN- $\alpha$ & [72] \\
\hline & & $\mathrm{IFN}-\gamma$ & [73] \\
\hline & Protease & $t-P A$ & [74] \\
\hline & & u-PA & {$[75,76]$} \\
\hline & & $\begin{array}{c}\text { MMP-1, }-2,-3,-7 \\
-9 \text { and }-12\end{array}$ & {$[10,12,51]$} \\
\hline \multirow[t]{10}{*}{ Mast cells } & Proangiogenic & VEGF & {$[77,78]$} \\
\hline & & bFGF & {$[79]$} \\
\hline & & TGF- $\beta$ & [80] \\
\hline & & TNF- $\alpha$ & [81] \\
\hline & & IL-8 & [81] \\
\hline & & Histamine & [48] \\
\hline & Protease & Chymase & {$[9,81,82]$} \\
\hline & & Tryptase & {$[9,81]$} \\
\hline & & MMP-9 & {$[12]$} \\
\hline & & Heparanase & [83] \\
\hline \multirow[t]{8}{*}{ Neutrophils } & Proangiogenic & VEGF & [84] \\
\hline & & IL-8 & [84] \\
\hline & Antiangiogenic & IL-12 & [84] \\
\hline & & IP-10 & [85] \\
\hline & & MIG & [85] \\
\hline & Protease & MMP-9 & [86] \\
\hline & & u-PA & {$[86]$} \\
\hline & & Elastase & {$[12,87]$} \\
\hline
\end{tabular}

bFGF, basic fibroblast growth factor; IFN, interferon; IP, interferon gamma inducible protein; MMP, matrix metalloprotease; PDGF, platelet-derived growth factor; TGF, transforming growth factor; TNF, tumour necrosis factor; TP, thymidine phosphorylase; t-PA, tissue-type plasminogen activator; u-PA, urokinase-type plasminogen activator; VEGF, vascular endothelial growth factor.

Monocytes are critical for the initiation of arteriogenesis because they adhere to and invade endothelium activated by the increased shear stress that results from large pressure differences between perfused areas [57]. The involvement of monocytes in arteriogenesis was discovered by Schaper et al. in 1976 [58], shortly before their role in angiogenesis in 1977 [7]. MCP-1 is once again implicated in this process because it not only attracts monocytes but also promotes their adhesion by inducing 
them to upregulate Mac-1, the receptor for intercellular adhesion molecule-1 (ICAM-1) that is expressed in activated endothelium [59]. Monocytes that adhere and then invade the arteriolar wall subsequently promote collateral artery growth by producing cytokines such as tumour necrosis factor- $\alpha$ and basic fibroblast growth factor [60]. Studies of collateral growth in rabbits have shown that, although prevention of monocyte adhesion (e.g. using antibodies to ICAM-1) delays arteriogenesis, infusion of MCP-1 or survival factors for monocytes (e.g. granulocyte-macrophage CSF) accelerate the process [57]. Although VEGF has also been shown to stimulate collateral growth, it now appears as though this positive effect of VEGF on arteriogenesis may be due principally to its effect on activating monocytes, stimulating their adhesion to the endothelium and their transmigration through it [61].

Although the large 'feeding vessels' that supply tumour vascular beds represent a potentially useful target for anticancer therapies, the exact mechanisms by which they are formed and recruited remains unknown. Again, the participation of monocytes/macrophages in this process has never been examined; however, given their importance in collateral formation, it is clear that they have the capability to play a considerable role. These issues are being actively pursued in our laboratory.

\section{Conclusion}

The recruitment of monocytes, macrophages and other inflammatory cells to a tumour appears to be a common denominator for the major processes involved in tumour development and progression (Fig. 1). Inflammatory cells contribute to tumour angiogenesis by supplying proangiogenic growth factors, cytokines and proteases. They also contribute factors that promote the formation and enlargement of intratumoural or peritumoural lymphatic vessels, eventually allowing a tumour to metastasize to distant organs. Finally, they may also play a critical role in arteriogenesis by promoting the growth of the larger vessels that supply the expanding capillary bed, feeding the rapidly growing tumour mass.

Is the recruitment of inflammatory cells a good target for cancer therapy? It is important to keep in mind that macrophages and other inflammatory cells, despite their proangiogenic and protumour effects, may also participate in antitumour immunosurveillance. The answer to this

This article is the second in a review series on Host microenvironment in breast cancer development, edited by Gloria Heppner.

Other articles in the series can be found at http://breast-cancer-research.com/ articles/series.asp?rqs=heppner
Figure 1

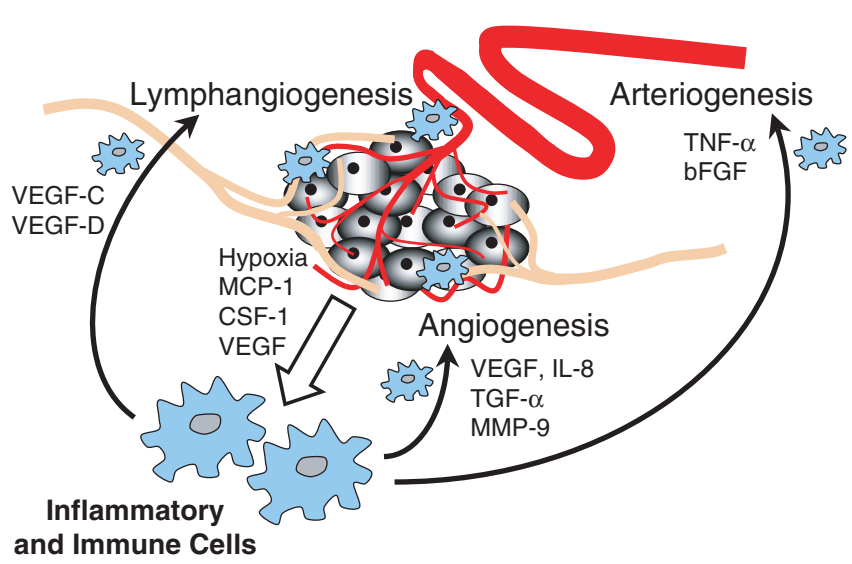

Inflammatory cells are recruited by tumours and play a supporting role during tumour progression, promoting tumour expansion by stimulating angiogenesis and arteriogenesis, and tumour metastasis through lymphangiogenesis. bFGF, basic fibroblast growth factor; CSF, colonystimulating factor; MCP, macrophage chemoattractant protein; MMP, matrix metalloprotease; TGF, transforming growth factor; TNF, tumour necrosis factor; VEGF, vascular endothelial growth factor.

question will probably depend on the type of tumour, on the stage at which inflammatory cells provide the greatest contribution during tumour progression, and on the nature of their influence (tumour-promoting or inhibitory). However, it could be speculated that simultaneously targeting the proarteriogenic effects of macrophages and the proangiogenic functions of endothelial cells may lead to synergistic antitumour effects, and exploration of this possibility is therefore warranted.

\section{Competing interests}

None declared.

\section{Acknowledgements}

We thank Dr Jeff Weitz and other colleagues at HRC for their encouragement during preparation of this manuscript. This work was supported by the Terry Fox Grant from the National Cancer Institute of Canada to JR. $\mathrm{JR}$ is the recipient of a Research Scientist Award from NCIC.

\section{References}

1. Dvorak HF: Tumors: wounds that do not heal. N Engl J Med 1986, 315:1650-1659.

2. Ravenswaay Claasen HH, Kluin PM, Fleuren GJ: Tumor infiltrating cells in human cancer. On the possible role of $\mathrm{CD}_{16}^{+}$ macrophages in antitumor cytotoxicity. Lab Invest 1992, 67:166174.

3. Rosenberg SA: Progress in human tumour immunology and immunotherapy. Nature 2001, 411:380-384.

4. Carr I: The Macrophage and Cancer. Edinburgh: Econoprint; 1977.

5. Urban JL, Shepard HM, Rothstein JL, Sugarman BJ, Schreiber H: Tumor necrosis factor: a potent effector molecule for tumor cell killing by activated macrophages. Proc Natl Acad Sci USA 1986, 83:5233-5237.

6. Pozzi LA, Weiser WY: Human recombinant migration inhibitory factor activates human macrophages to kill tumor cells. Cell Immunol 1992, 145:372-379.

7. Polverini PJ, Cotran RS, Gimbrone MA, Unanue ER: Activated macrophages induce vascular proliferation. Nature 1977, 269:804-806. 
8. Sidky YA, Auerbach R: Lymphocyte-induced angiogenesis: a quantitative and sensitive assay of the graft-vs-host reaction. $J$ Exp Med 1975, 141:1084-1100.

9. Coussens LM, Raymond WW, Bergers G, Laig-Webster M, Behrendtsen O, Werb Z, Caughey GH, Hanahan D: Inflammatory mast cells up-regulate angiogenesis during squamous epithelial carcinogenesis. Genes Dev 1999, 13:1382-1397.

10. Bingle L, Brown NJ, Lewis CE: The role of tumour-associated macrophages in tumour progression: implications for new anticancer therapies. J Pathol 2002, 196:254-265.

11. Crowther M, Brown NJ, Bishop ET, Lewis CE: Microenvironmental influence on macrophage regulation of angiogenesis in wounds and malignant tumors. J Leukoc Biol 2001, 70:478490.

12. Coussens LM, Tinkle CL, Hanahan D, Werb Z: MMP-9 supplied by bone marrow-derived cells contributes to skin carcinogenesis. Cell 2000, 103:481-490.

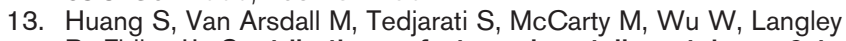
R, Fidler IJ: Contributions of stromal metalloproteinase-9 to angiogenesis and growth of human ovarian carcinoma in mice. J Natl Cancer Inst 2002, 94:1134-1142.

14. Kalra VK, Shen Y, Sultana C, Rattan V: Hypoxia induces PECAM-1 phosphorylation and transendothelial migration of monocytes. Am J Physiol 1996, 271:H2025-H2034.

15. Leek RD, Lewis CE, Whitehouse R, Greenall M, Clarke J, Harris AL: Association of macrophage infiltration with angiogenesis and prognosis in invasive breast carcinoma. Cancer Res 1996, 56:4625-4629.

16. Turner L, Scotton C, Negus R, Balkwill F: Hypoxia inhibits macrophage migration. Eur J Immunol 1999, 29:2280-2287.

17. Leek RD, Landers RJ, Harris AL, Lewis CE: Necrosis correlates with high vascular density and focal macrophage infiltration in invasive carcinoma of the breast. Br J Cancer 1999, 79:991-995.

18. Lewis JS, Landers RJ, Underwood JC, Harris AL, Lewis CE: Expression of vascular endothelial growth factor by macrophages is up-regulated in poorly vascularized areas of breast carcinomas. J Pathol 2000, 192:150-158.

19. Lee AH, Happerfield LC, Bobrow LG, Millis RR: Angiogenesis and inflammation in invasive carcinoma of the breast. J Clin Pathol 1997, 50:669-673.

20. Volodko N, Reiner A, Rudas M, Jakesh R: Tumour-associated macrophages in breast cancer and their prognostic correlations. Breast 1998, 7:99-105.

21. Goede V, Brogelli L, Ziche M, Augustin HG: Induction of inflammatory angiogenesis by monocyte chemoattractant protein-1. Int J Cancer 1999, 82:765-770.

22. Tang RP, Kacinski $B$, Validire $P$, Beuvon $F$, Sastre $X$, Benoit $P$, dela Rochefordiere A, Mosseri V, Pouillart P, Scholl S: Oncogene amplification correlates with dense lymphocyte infiltration in human breast cancers: a role for hematopoietic growth factor release by tumor cells? J Cell Biochemistry 1990, 44:189-198.

23. van Golen KL, Wu ZF, Qiao XT, Bao L, Merajver SD: RhoC GTPase overexpression modulates induction of angiogenic factors in breast cells. Neoplasia 2000, 2:418-425.

24. Graves DT, Jiang YL, Williamson MJ, Valente AJ: Identification of monocyte chemotactic activity produced by malignant cells. Science 1989, 245:1490-1493.

25. Yoshimura T, Robinson EA, Tanaka S, Appella E, Kuratsu J, Leonard EJ: Purification and amino acid analysis of two human glioma-derived monocyte chemoattractants. J Exp Med 1989, 169:1449-1459.

26. Negus RP, Stamp GW, Relf MG, Burke F, Malik ST, Bernasconi S et al:: The detection and localization of monocyte chemoattractant protein-1 (MCP-1) in human ovarian cancer. J Clin Invest 1995, 95:2391-2396.

27. Sato K, Kuratsu J, Takeshima H, Yoshimura T, Ushio Y: Expression of monocyte chemoattractant protein-1 in meningioma. $J$ Neurosurg 1995, 82:874-878.

28. Valkovic T, Dobrila F, Melato M, Sasso F, Rizzardi C, Jonjic N: Correlation between vascular endothelial growth factor, angiogenesis, and tumor-associated macrophages in invasive ductal breast carcinoma. Virchows Arch 2002, 440:583-588.

29. Saji H, Koike M, Yamori T, Saji S, Seiki M, Matsushima K, Toi M: Significant correlation of monocyte chemoattractant protein-1 expression with neovascularization and progression of breast carcinoma. Cancer 2001, 92:1085-1091.

30. Ueno T, Toi M, Saji H, Muta M, Bando H, Kuroi K, Koike M,
Inadera $\mathrm{H}$, Matsushima K: Significance of macrophage chemoattractant protein-1 in macrophage recruitment, angiogenesis, and survival in human breast cancer. Clin Cancer Res 2000, 6:3282-3289.

31. Ferrara N, Davis-Smyth T: The biology of vascular endothelial growth factor. Endocr Rev 1997, 18:4-25.

32. Clauss M, Gerlach M, Gerlach H, Brett J, Wang F, Familletti PC, Pan YC, Olander JV, Connolly DT, Stern D: Vascular permeability factor: a tumor-derived polypeptide that induces endothelial cell and monocyte procoagulant activity, and promotes monocyte migration. J Exp Med 1990, 172:1535-1545.

33. Barleon B, Sozzani S, Zhou D, Weich HA, Mantovani A, Marme D: Migration of human monocytes in response to vascular endothelial growth factor (VEGF) is mediated via the VEGF receptor fit-1. Blood 1996, 87:3336-3343.

34. Sawano A, Iwai $S$, Sakurai $Y$, Ito $M$, Shitara $K$, Nakahata $T$, Shibuya M: Flt-1, vascular endothelial growth factor receptor 1 , is a novel cell surface marker for the lineage of monocytemacrophages in humans. Blood 2001, 97:785-791.

35. Leek RD, Hunt NC, Landers RJ, Lewis CE, Royds JA, Harris AL: Macrophage infiltration is associated with VEGF and EGFR expression in breast cancer. J Pathol 2000, 190:430-436.

36. Duyndam MC, Hilhorst MC, Schluper HM, Verheul HM, van Diest PJ, Kraal G, Pinedo HM, Boven E: Vascular endothelial growth factor-165 overexpression stimulates angiogenesis and induces cyst formation and macrophage infiltration in human ovarian cancer xenografts. Am J Patho/ 2002, 160:537-548.

37. Yeo KT, Wang HH, Nagy JA, Sioussat TM, Ledbetter SR, Hoogewerf AJ, Zhou Y, Masse EM, Senger DR, Dvorak HF, et al:: Vascular permeability factor (vascular endothelial growth factor) in guinea pig and human tumor and inflammatory effusions. Cancer Res 1993, 53:2912-2918.

38. Clauss M, Weich H, Breier G, Knies U, Rockl W, Waltenberger J, Risau W: The vascular endothelial growth factor receptor Flt-1 mediates biological activities. Implications for a functional role of placenta growth factor in monocyte activation and chemotaxis. J Biol Chem 1996, 271:17629-17634.

39. Skobe M, Hamberg LM, Hawighorst T, Schirner M, Wolf GL, Alitalo K, Detmar M: Concurrent induction of lymphangiogenesis, angiogenesis, and macrophage recruitment by vascular endothelial growth factor-C in melanoma. Am J Pathol 2001, 159:893-903.

40. Adini A, Kornaga T, Firoozbakht F, Benjamin LE: Placental growth factor is a survival factor for tumor endothelial cells and macrophages. Cancer Res 2002, 62:2749-2752.

41. Stanley ER, Guilbert LJ, Tushinski RJ, Bartelmez SH: CSF-1: a mononuclear phagocyte lineage-specific hemopoietic growth factor. J Cell Biochem 1983, 21:151-159.

42. Ramakrishnan S, Xu FJ, Brandt SJ, Niedel JE, Bast RC Jr, Brown EL: Constitutive production of macrophage colony-stimulating factor by human ovarian and breast cancer cell lines. J Clin Invest 1989, 83:921-926.

43. Tang R, Beuvon F, Ojeda M, Mosseri V, Pouillart P, Scholl S: MCSF (monocyte colony stimulating factor) and M-CSF receptor expression by breast tumour cells: M-CSF mediated recruitment of tumour infiltrating monocytes? J Cell Biochem 1992, 50:350-356.

44. Kacinski BM: CSF-1 and its receptor in ovarian, endometrial and breast cancer. Ann Med 1995, 27:79-85.

45. Nowicki A, Szenajch J, Ostrowska G, Wojtowicz A, Wojtowicz K, Kruszewski AA, Maruszynski M, Aukerman SL, Wiktor-Jedrzejczak $\mathrm{W}$ : Impaired tumor growth in colony-stimulating factor 1 (CSF-1)-deficient, macrophage-deficient op/op mouse: evidence for a role of CSF-1-dependent macrophages in formation of tumor stroma. Int J Cancer 1996, 65:112-119.

46. Lin EY, Nguyen AV, Russell RG, Pollard JW: Colony-stimulating factor 1 promotes progression of mammary tumors to malignancy. J Exp Med 2001, 193:727-740.

47. Sunderkotter C, Steinbrink K, Goebeler M, Bhardwaj R, Sorg C: Macrophages and angiogenesis. J Leukoc Biol 1994, 55:410422.

48. Sorbo J, Jakobsson A, Norrby K: Mast-cell histamine is angiogenic through receptors for histamine1 and histamine2. Int $J$ Exp Pathol 1994, 75:43-50.

49. Pepper MS: Role of the matrix metalloproteinase and plasminogen activator-plasmin systems in angiogenesis. Arterioscler Thromb Vasc Biol 2001, 21:1104-1117. 
50. Maeshima Y, Sudhakar A, Lively JC, Ueki K, Kharbanda S, Kahn CR, Sonenberg N, Hynes RO, Kalluri R: Tumstatin, an endothelial cell-specific inhibitor of protein synthesis. Science 2002, 295:140-143.

51. Dong Z, Kumar R, Yang X, Fidler IJ: Macrophage-derived metalloelastase is responsible for the generation of angiostatin in Lewis lung carcinoma. Cell 1997, 88:801-810.

52. Patterson BC, Sang QA: Angiostatin-converting enzyme activities of human matrilysin (MMP-7) and gelatinase B/type IV collagenase (MMP-9). J Biol Chem 1997, 272:28823-28825.

53. Jussila L, Alitalo K: Vascular growth factors and lymphangiogenesis. Physiol Rev 2002, 82:673-700.

54. Schoppmann SF, Birner P, Stockl J, Kalt R, Ullrich R, Caucig C, Kriehuber E, Nagy K, Alitalo K, Kerjaschki D: Tumor-associated macrophages express lymphatic endothelial growth factors and are related to peritumoral lymphangiogenesis. $A m \mathrm{~J}$ Pathol 2002, 161:947-956.

55. Padera TP, Kadambi A, di Tomaso E, Carreira CM, Brown EB, Boucher Y, Choi NC, Mathisen D, Wain J, Mark EJ, Munn LL, Jain RK: Lymphatic metastasis in the absence of functional intratumor lymphatics. Science 2002, 296:1883-1886.

56. Folkman J: Tumor angiogenesis. In Cancer Medicine. Edited by Holland JF, Bast RC, Morton DL, Frei E, Kufe DW, Weichselbaum RR. Baltimore: Williams \& Wilkins; 1997:181-204.

57. Scholz D, Cai WJ, Schaper W: Arteriogenesis, a new concept of vascular adaptation in occlusive disease. Angiogenesis 2001, 4:247-257.

58. Schaper J, Konig R, Franz D, Schaper W: The endothelial surface of growing coronary collateral arteries. Intimal margination and diapedesis of monocytes. A combined SEM and TEM study. Virchows Arch A Pathol Anat Histol 1976, 370:193-205.

59. Scholz D, Ito W, Fleming I, Deindl E, Sauer A, Wiesnet M, Busse R, Schaper J, Schaper W: Ultrastructure and molecular histology of rabbit hind-limb collateral artery growth (arteriogenesis). Virchows Arch 2000, 436:257-270.

60. Arras M, Ito WD, Scholz D, Winkler B, Schaper J, Schaper W: Monocyte activation in angiogenesis and collateral growth in the rabbit hindlimb. J Clin Invest 1998, 101:40-50.

61. Heil M, Clauss M, Suzuki K, Buschmann IR, Willuweit A, Fischer S, Schaper W: Vascular endothelial growth factor (VEGF) stimulates monocyte migration through endothelial monolayers via increased integrin expression. Eur J Cell Biol 2000, 79:850-857.

62. Xiong M, Elson G, Legarda D, Leibovich SJ: Production of vascular endothelial growth factor by murine macrophages: regulation by hypoxia, lactate, and the inducible nitric oxide synthase pathway. Am J Pathol 1998, 153:587-598.

63. Madtes DK, Raines EW, Sakariassen KS, Assoian RK, Sporn MB, Bell Gl, Ross R: Induction of transforming growth factor-alpha in activated human alveolar macrophages. Cell 1988, 53:285293.

64. Rappolee DA, Mark D, Banda MJ, Werb Z: Wound macrophages express TGF-alpha and other growth factors in vivo: analysis by mRNA phenotyping. Science 1988, 241:708-712.

65. Koch AE, Polverini PJ, Kunkel SL, Harlow LA, DiPietro LA, Elner VM, Elner SG, StrieterRM: Interleukin-8 as a macrophage-derived mediator of angiogenesis. Science 1992, 258:1798-1801.

66. Leek RD, Harris AL, Lewis CE: Cytokine networks in solid human tumors: regulation of angiogenesis. J Leukoc Biol 1994, 56:423-435.

67. Nagaoka $H$, lino $Y$, Takei $H$, Morishita $Y$ : Platelet-derived endothelial cell growth factor/thymidine phosphorylase expression in macrophages correlates with tumor angiogenesis and prognosis in invasive breast cancer. Int J Oncol 1998, 13:449-454.

68. Martinet Y, Bitterman PB, Mornex JF, Grotendorst GR, Martin GR, Crystal RG: Activated human monocytes express the c-sis proto-oncogene and release a mediator showing PDGF-like activity. Nature 1986, 319:158-160.

69. Ziche M, Morbidelli L, Geppetti P, Maggi CA, Dolara P: Substance $P$ induces migration of capillary endothelial cells: a novel NK-1 selective receptor mediated activity. Life Sci 1991, 48:L7-L11.

70. Humes JL, Bonney RJ, Pelus L, Dahlgren ME, Sadowski SJ, Kuehl FA Jr, Davies P: Macrophages synthesis and release prostaglandins in response to inflammatory stimuli. Nature 1977, 269:149-151.
71. Jaffe EA, Ruggiero JT, Falcone DJ: Monocytes and macrophages synthesize and secrete thrombospondin. Blood 1985 65:79-84.

72. Fleit HB, Rabinovitch $M$ : Production of interferon by in vitro derived bone marrow macrophages. Cell Immunol 1981, 57:495-504.

73. Robinson BW, McLemore TL, Crystal RG: Gamma interferon is spontaneously released by alveolar macrophages and lung $T$ lymphocytes in patients with pulmonary sarcoidosis. $J$ Clin Invest 1985, 75:1488-1495.

74. Klimetzek V, Sorg C: Lymphokine-induced secretion of plasminogen activator by murine macrophages. Eur J Immunol 1977, 7:185-187

75. Xu Y, Hagege J, Doublet JD, Callard P, Sraer JD, Ronne E, Rondeau E: Endothelial and macrophage upregulation of urokinase receptor expression in human renal cell carcinoma. Hum Pathol 1997, 28:206-213.

76. Hildenbrand R, Dilger I, Horlin A, Stutte HJ: Urokinase and macrophages in tumour angiogenesis. $\mathrm{Br} J$ Cancer 1995 72:818-823.

77. Boesiger J, Tsai M, Maurer M, Yamaguchi M, Brown LF, Claffey KP, Dvorak HF, Dalli SJ: Mast cells can secrete vascular permeability factor/ vascular endothelial cell growth factor and exhibit enhanced release after immunoglobulin E-dependent upregulation of fc epsilon receptor I expression. J Exp Med 1998, 188:1135-1145.

78. Grutzkau A, Kruger-Krasagakes S, Baumeister H, Schwarz C, Kogel H, Welker P, Lippert U, Henz BM, Moller A: Synthesis, storage, and release of vascular endothelial growth factor/vascular permeability factor (VEGF/VPF) by human mast cells: implications for the biological significance of VEGF206. Mol Biol Cell 1998, 9:875-884.

79. Reed JA, Albino AP, McNutt NS: Human cutaneous mast cells express basic fibroblast growth factor. Lab Invest 1995, 72:215-222.

80. Pennington DW, Lopez AR, Thomas PS, Peck C, Gold WM: Dog mastocytoma cells produce transforming growth factor beta 1. J Clin Invest 1992, 90:35-41.

81. Metcalfe DD, Baram D, Mekori YA: Mast cells. Physiol Rev 1997, 77:1033-1079.

82. Norrby K: Mast cells and angiogenesis. Acta Path Microbiol Scand 2002, 110:355-371.

83. Bashkin P, Razin E, Eldor A, Vlodavsky I: Degranulating mast cells secrete an endoglycosidase that degrades heparan sulfate in subendothelial extracellular matrix. Blood 1990 75:2204-2212.

84. Cassatella MA: Neutrophil-derived proteins: selling cytokines by the pound. Adv Immunol 1999, 73:369-509.

85. Gasperini S, Marchi M, Calzetti F, Laudanna C, Vicentini L, Olsen $H$, Murphy M, Liao F, Farber J, Cassatella MA: Gene expression and production of the monokine induced by IFN-gamma (MIG), IFN-inducible T cell alpha chemoattractant (I-TAC), and IFN-gamma-inducible protein-10 (IP-10) chemokines by human neutrophils. J Immunol 1999, 162:4928-4937.

86. Borregaard N, Cowland JB: Granules of the human neutrophilic polymorphonuclear leukocyte. Blood 1997, 89:3503-3521.

87. Scapini P, Nesi L, Morini M, Tanghetti E, Belleri M, Noonan D, Presta M, Albini A, Cassatella MA: Generation of biologically active angiostatin kringle 1-3 by activated human neutrophils. $\mathrm{J}$ Immunol 2002, 168:5798-5804.

\section{Correspondence}

Janusz W Rak, Henderson Research Centre, McMaster University, 711 Concession St., Hamilton, Ontario, Canada L8V 1C3. Tel: +1 905527 2299 ext. 43771; fax: +1 905575 2646; e-mail: jrak@thrombosis. hhscr.org 